\title{
PENGARUH FAKTOR INTERNAL DAN EKSTERNAL TERHADAP RETURN SAHAM DENGAN MODERASI GOOD CORPORATE GOVERNANCE (GCG)
}

\author{
Alexsander Bagaswara ${ }^{1}$, Lela Nurlaela Wati ${ }^{2}$ \\ ${ }^{1}$ STIE Kusuma Negara, alexander.bagaswara@yahoo.com \\ ${ }^{2}$ STIE Muhammadiyah Jakarta, lela_nwm@yahoo.com; lela@stiemj.ac.id
}

\begin{abstract}
ABSTRAK
Tujuan penelitian ini untuk menganalisis pengaruh faktor eksternal dan internal perusahaan terhadap return saham dengan moderasi Good Corporate Governance (GCG) pada sektor perbankan yang terdaftar di BEI tahun 2014-2018. Penelitian ini menggunakan 20 perusahaan sebagai sampel dari total 42 perusahaan sektor perbankan yang terdaftar di Bursa Efek Indonesia dan menerbitkan annual report tahun 2014-2018 (100 panel data). Metode analisis yang digunakan adalah metode analasis regresi data panel dengan menggunakan software Eviews. Hasil penelitian menunjukkan bahwa tingkat suku bunga dan kurs (faktor eksternal), aktivitas, dan mekanisme GCG (faktor internal) berpengaruh signifikan terhadap retrun saham. Namun, inflasi dan profitabilitas tidak berpengaruh terhadap return saham. Begitu pula dengan GCG yang diproksi oleh dewan komisaris independen tidak mampu memperkuat pengaruh Profitabilitas dan Aktivitas terhadap return saham. Implikasi dari hasil penelitian ini, manajemen agar terus meningkatkan efektifitas dan efisiensi agar kinerja perbankan terus meningkat karena akan berdampak terhadap harga dan return saham. Bagi investor, agar memperhatikan rasio Total Asset Turn Over untuk menilai tingkat efektifitas dan efisiensi perbankan sebelum menginvestasikan dana di perusahaan juga melihat mekanisme Corporate Governance di perbankan. Investor juga harus memperhatikan nilai kurs dan tingkat suku bunga saat mau menginvestasikan dananya di perbankan karena berdampak terhadap return saham.
\end{abstract}

Kata Kunci: Return Saham, Kinerja Keuangan, GCG, Inflasi, Kurs, Tingkat Bunga.

\begin{abstract}
The purpose of this study is to analyze the influence of external and internal factors on stock returns moderated by Good Corporate Governance (GCG) in the banking sector listed on the IDX in 2014 2018. This study uses 20 companies as a sample of a total of 42 banking sector companies listed on the Indonesia Stock Exchange and publishes the 2014-2018 annual report (100 panel data). The analytical method used is the panel data regression analysis method using Eviews software. The results showed that the interest rate and exchange rate (external factors), activity, and the GCG mechanism (internal factors) had a significant effect on stock retraction. However, inflation and profitability have no effect on stock returns. Likewise, GCG which is proxied by the independent board of commissioners is not able to strengthen the effect of Profitability and Activity on stock returns. The implication of this research is that management should continue to improve effectiveness and efficiency so that banking performance will continue to increase because it will have an impact on stock prices and returns. For investors, to pay attention to the Total Asset Turn Over ratio to assess the level of effectiveness and efficiency of banks before investing funds in the company, also see the mechanism of corporate governance in banking. Investors must also pay attention to exchange rates and interest rates when they want to invest their funds in banks because they have an impact on stock returns.
\end{abstract}

Keywords: Stock Return, Financial Performance, GCG, Inflation, Exchange Rates, Interest Rates.

Naskah diterima : 25-09-2020, Naskah dipublikasikan : 30-09-2020 


\section{JURNAL EKOBIS: EKONOMI, BISNIS \& MANAJEMEN}

Vol 10 Nomor 2 (2020)

\section{PENDAHULUAN}

Perbankan merupakan salah satu sistem keuangan yang berfungsi sebagai lembaga penghubung keuangan (financial intermediary), yaitu suatu lembaga yang mempunyai peran untuk mempertemukan dan menjembatani antara penyandang dan pengguna dana. Oleh karena itu, kegiatan bank harus berjalan secara efisien pada skala makro maupun mikro (Rachman dkk, 2019). Efektifitas dan efisiensi perbankan akan meningkatka kinerjanya sehingga investor akan tertarik untuk menginvetasikan dananya pada saham perbankan tersebut yang berdampak terhadap peningkatan harga dan return saham. Investor harus memahami kinerja sahamnya untuk menentukan investasi terbaik. Pemahaman analisis risk dan return dari suatu investasi harus diketahui oleh seorang investor (Hakim et al., 2020).

Return saham merupakan tingkat pengembalian berupa imbalan yang diperoleh dari hasil jual beli saham. Investasi dalam bentuk saham merupakan investasi yang berisiko, karena itu untuk menarik investor dengan menawarkan tingkat keuntungan yang lebih tinggi dibandingkan dengan tingkat keuntungan investasi lainnya yang kurang berisiko. Dari hal tersebut investor membutuhkan berbagai informasi yang dijadikan sebagai sinyal untuk menilai prospek perusahaan yang bersangkutan yaitu dengan menganalisis laporan kinerja keuangan. Kinerja keuangan merupakan factor internal perusahaan yang dapat diukur melalui rasio-rasio keuangan yaitu likuiditas, solvabilitas, aktifitas dan profitabilitas. Selain kinerja keuangan, mkanisme Corporate Governance juga merupakan factor yang menentukan kinerja pasar perusahaan. Adapun faktor eksternal yang dapat mempengaruhi return saham yaitu seperti kebijakan fiskal dan moneter, perkembangan industri tersebut, dan faktor ekonomi seperti tingkat inflasi, perubahan nilai tukar, dan tingkat suku bunga, dan lain sebagainya.

Inflasi diartikan sebagai meningkatnya harga-harga secara terus-menerus. Menurut (Dwijayanty, 2009) menyatakan bahwa inflasi adalah kecenderungan dari harga-harga untuk menaikkan secara umum dan terus menerus dalam jangka waktu yang lama. Kenaikan harga dari satu atau dua barang saja tidak disebut inflasi, kecuali bila kenaikan tersebut meluas kepada (atau mengakibatkan kenaikan) sebagian besar dari harga barang-barang lain.

Sasaran inflasi merupakan tingkat inflasi yang harus dicapai oleh bank indonesia untuk berkoordinasi dengan pemerintah. Penetapan sasaran inflasi berdasarkan undang-undang mengenai bank indonesia, sasaran inflasi ditetapkan 3 tahun kedepan melalui peraturan yang sudah dibuat oleh menteri keuangan di indonesia yang berdasarkan PMK No.93/PMK.011/2014 tentang sasaran inflasi pada tahun 2014, 2015 dan 2016. Sasaran dengan divisiasi masing-masing 1\% dan masing-masing sebesar 4,5\%,4\%,dan 4\%. Sasaran inflasi tersebut diharapkan sebagai acuan bagi pelaku usaha dan masyarakat dalam melakukan kegiatan ekonominya kedepan sehingga dalam tingkat inflasi bisa diturunkan pada tingkat yang rendah dan stabil dalam perekonomian.

Menurut Almar'atus Sholikhah (2014), kurs (exchange rate) atau nilai tukar kurs adalah pertukaran antara dua mata uang yang berbeda, yaitu merupakan perbandingan nilai atau harga antara kedua mata uang, misalnya perbandingan antara nilai mata uang rupiah dengan dollar AS. Kurs rupiah terhadap dollar AS dari tahun 2014 - 2018 dapat dilihat pada tabel berikut:

Tabel 1. Kurs Rupiah terhadap Dollar AS

\begin{tabular}{|c|c|c|c|}
\hline Nilai & Kurs Jual & Kurs Beli & Tanggal \\
\hline 1,00 & 12,502 & 12,378 & $31-12-2014$ \\
\hline 1,00 & 13,864 & 13,726 & $30-12-2015$ \\
\hline 1,00 & 13,503 & 13,369 & $30-12-2016$ \\
\hline 1,00 & 13,616 & 13,480 & $29-12-2017$ \\
\hline 1,00 & 14,553 & 14,409 & $31-12-2018$ \\
\hline
\end{tabular}

Sumber: www.bi.go.id 
Berdasarkan tabel di atas, kurs jual maupun kurs beli rupiah terhadap dollar AS dari tahun 2014 - 2018 semakin meningkat yang berarti bahwa untuk mendapatkan 1 dollar AS, membutuhkan rupiah semakin banyak. Hal ini menunjukkan bahwa nilai tukar rupiah terhadap dollar AS semakin melemah. Melemahnya nilai tukar rupiah terhadap dollar AS dapat menyebabkan menurunnya kinerja ekonomi Indonesia sehingga dapat mempengaruhi minat investor dalam berinvestasi, termasuk investasi di perusahaan perbankan.

Return Saham memberikan fasilitas untuk mempertemukan antara pihak-pihak surplus dana dengan pihak yang membutuhkan dana dalam rangka investasi (Hadi, 2013). Di situlah pasar modal memiliki peran penting, mengingat pertumbuhan investasi berarti terjadi pergerakan ekonomi secara circle, mulai dari sektor keuangan sampai dengan sektor riil (Darmawi, 2006: 9). Saham juga dikatakan memiliki fungsi keuangan, karena di dunia sekarang memberikan kemungkinan dan kesempatan memperoleh return saham bagi pemilik dana (Fakhruddin dan Hadianto, 2001: 12).

Tabel.2. Rata-rata Return Saham, Inflasi, Nilai Tukar Rupiah per Dollar AS, Suku Bunga, ROA dan ROE.

\begin{tabular}{|l|l|l|l|l|l|}
\hline Variabel & $\mathbf{2 0 1 4}$ & $\mathbf{2 0 1 5}$ & $\mathbf{2 0 1 6}$ & $\mathbf{2 0 1 7}$ & $\mathbf{2 0 1 8}$ \\
\hline Return Saham & 0,38 & 0,39 & 0,34 & -0.08 & 0,15 \\
\hline Inflasi & $4,28 \%$ & $6,79 \%$ & $6,42 \%$ & $6,38 \%$ & $3,53 \%$ \\
\hline $\begin{array}{l}\text { Nilai Tukar Rp/Dollar } \\
\text { AS }\end{array}$ & 12,502 & 13,864 & 13,503 & 13,616 & 14,553 \\
\hline Suku Bunga & $5,77 \%$ & $6,48 \%$ & $7,53 \%$ & $7,52 \%$ & $6,00 \%$ \\
\hline ROA & -0.12 & 0,07 & 0,07 & 0,05 & 0,06 \\
\hline ROE & -0.11 & 0,05 & 0,05 & 0,03 & 0,04 \\
\hline TATO & 0.090 & 0.088 & 0.084 & 0.079 & 0.066 \\
\hline
\end{tabular}

Sumber: www.bi.go.id, Data diolah, 2019

Pada Tabel 2 di atas terlihat bahwa kondisi di Bursa Efek Indonesia (BEI) dalam kurun waktu tahun 2014 sampai dengan 2018 mengalami fluktuasi. Besarnya rata-rata Return Saham tertinggi terjadi pada tahun 2015 sebesar 0,39, sedangkan rata-rata Return Saham terendah terjadi pada tahun 2017 yaitu sebesar $-0,08$. Berdasarkan Tabel 2 tersebut, terlihat bahwa ada beberapa nilai TATO yang mengalami penurunan pada tahun 2018, Inflasi, Nilai Tukar Rupiah per Dolar AS, Return on Assets (ROA), dan Return on Equity (ROE), menunjukkan kondisi yang tidak konsisten dengan Return Saham Pada perbankan di Bursa Efek Indonesia periode 2014 hingga 2018. Menurut Ang (1997: 130), semakin baik kinerja keuangan perusahaan yang tercermin dari rasio-rasio, maka akan semakin tinggi return saham perusahaan. Demikian juga jika kondisi ekonomi baik, maka refleksi harga saham akan semakin baik pula.

Penelitian mengenai pengaruh kinerja keuangan yang diproksi oleh Total Asset Turn Over (TATO) terhadap return saham pernah dilakukan oleh Widodo (2007), hasil dari penelitian tersebut menunjukkan bahwa TATO berpengaruh signifikan terhadap Return saham. Penelitian dengan menggunakan TATO juga pernah dilakukan oleh Saniman (2006), yang menguji manfaat informasi akuntansi dalam memprediksi return saham, ditemukan bahwa rasio aktivitas tidak bermanfaat untuk memprediksi return dua tahun ke depan. Kemungkinan perbedaan ini karena perbedaan sampel dan ukuran perusahaan. Pengaruh TATO pada return saham juga dilakukan oleh Ulupui (2014) perihal emiten return saham sektor perbankan. Hasilnya menyimpulkan bahwa TATO berpengaruh signifikan terhadap Return saham. 
Menurut Wati et al (2016) dan Wati (2017), mekanisme Good Corporate Governance dapat dilakukan melalui mekamisme eksternal dan internal. Mekanisme kontrol eksternal merupakan pengendalian perusahaan berdasarkan mekanisme pasar, sedangkan mekanisme internal adalah pengendalian yang dilakukan oleh dewan komisaris termasuk komite-komite di bawahnya, dewan direksi, manajemen dan para pemegang saham, atau melalui skema insentif yang menarik dan kompetitif untuk manajemen. Selain memiliki kinerja keuangan yang baik, perusahaan diharapkan juga memiliki tata kelola yang baik. Pengelolaan perusahaan yang baik akan mempengaruhi stakeholders untuk mau berinvestasi pada perusahaan tersebut.

Dalam penelitian Hermawati (2012) kinerja keuangan diproksikan dengan return on equity (ROE). Variabel ROE merupakan salah satu variabel yang terpenting yang dilihat investor sebelum berinvestasi. ROE merupakan kemampuan perusahaan dalam menghasilkan keuntungan dengan model sendiri yang dimiliki. Rasio ini merupakan ukuran profitabilitas dari sudut pemegang saham semakin tinggi rasio ini maka semakin besar profitabilitas perusahaan, yang pada akhirnya dapat menjadi sinyal positif bagi para investor dalam melakukan investasi untuk memperoleh return tertentu. Tingkat return yang diperoleh menggambarkan seberapa baik nilai perusahaan dimata investor. Apabila perusahaan berhasil membukukan tingkat keuntungan yang besar, maka hal ini akan memotivasi para investor untuk menanamkan modalnya pada saham, sehingga pada harga saham dan permintaan akan saham pun akan meningkat. Penelitian ini menambahkan faktor lain yang dimungkinkan turut mempengaruhi hubungan ROE dengan return saham yaitu pengungkapan good corporate governance (GCG) sebagai variabel moderasi yang diduga ikut memperlemah pengaruh tersebut.

Berdasakan uraian di atas, maka penelitian ini bertujuan untuk menguji pengaruh kinerja keuangan, mekanisme GCG sebagai faktor internal perusahaan dan inflasi, kurs mata uang, dan tingkat suku bunga sebagai faktor eksternal perusahaan terhadap return saham. Penelitian ini berbeda dengan peneliti sebelumnya karena menggunakan variable moderasi yaitu mekanisme Corporate Governance sebagai variable moderasi.

\section{KAJIAN LITERATUR Return Saham}

Menurut Tandelilin (2010:10), return dapat berupa return aktual (realisasi) yang sudah terjadi dan return harapan (ekspektasi) yang belum terjadi tetapi diharapkan akan terjadi di masa mendatang. Pendapatan investasi dalam saham ini merupakan keuntungan yang diperoleh dari jual beli saham, di mana jika untung disebut capital gain dan jika rugi disebut capital loss. Tujuan investor dalam berinvestasi dapat memaksimalkan return, tanpa melupakan faktor risiko investasi yang harus dihadapinya. Return merupakan salah satu faktor yang motivasi investor berinvestasi dan juga merupakan imbalan atas jasa keberanian investor menanggung risiko.

Secara matematis, perhitungan return saham adalah sebagai berikut.

$$
\text { Return Saham }=\frac{P_{t}-P_{t-1} \times 100 \%}{P_{t-1}}
$$

Keterangan:

Rit : tingkat keuntungan saham I pada periode $t$

Pit : harga penutupan saham I pada periode $\mathrm{t}$ (periode penutupan/akhir)

Pit-1 : harga penutupan saham I pada periode sebelumnya 


\section{Vol 10 Nomor 2 (2020)}

\section{Inflasi}

Inflasi adalah suatu proses meningkatnya harga-harga secara umum dan terus menerus, berkaitan dengan mekanisme pasar yang dapat disebabkan oleh berbagai faktor, antara lain, konsumsi masyarakat yang meningkat, berlebihnya likuiditas di pasar yang memicu konsumsi atau bahkan spekulasi, sampai termasuk juga akibat adanya ketidak lancaran distribusi barang (Wibowo, 2012: 19). Dapat diartikan sebagai proses menurunnya nilai mata uang secara kontinu. Inflasi adalah proses dari suatu peristiwa, bukan tinggi-rendahnya tingkat harga. Inflasi adalah indikator untuk melihat tingkat perubahan, dan dianggap terjadi jika proses kenaikan harga berlangsung secara terus-menerus dan saling pengaruh-memengaruhi Wibowo (2012:19). Istilah inflasi juga digunakan untuk mengartikan peningkatan persediaan uang yang kadangkala dilihat sebagai penyebab meningkatnya harga.

\section{Rate/ Suku Bunga}

Kebijakan moneter sangat dipengaruhi oleh ketepatan tingkat suku bunga yang ideal, harus tercipta keseimbangan antara manfaat suku bunga bagi sektor perbankan dan dunia usaha, supaya kestabilan ekonomi Negara tetap terjaga. Menurut ww.bi.go.id menyatakan bahwa tingkat suku bunga BI atau BI Rate adalah suku bunga kebijakan yang mencerminkan sikap atau stance,kebijakan moneter yang ditetapkan oleh Bank Indonesia dan diumumkan kepada public.

\section{Kurs atau nilai tukar (Foreign exchange rate)}

Mencerminkan berapa unit dari mata uang lokal yang dapat dipergunakan untuk membeli mata uang lainnya. Dampak dari perubahan nilai tukar atas suatu bisnis dapat dilihat dari penguatan atau pelemahan suatu mata uang, tetapi juga dengan memperhatikan apakah negara tersebut adalah net exporter atau net importer Mayfi dan Rudianto (2014). Perubahan nilai tukar dipengaruhi oleh banyak faktor seperti yang diungkapkan yaitu tingkat suku bunga, inflasi, jumlah uang beredar, defisit perdagangan, perilaku bank sentral yang terkait dengan independensi bank sentral, dan harapan pasar (market expectation). Dan untuk variabel kurs ini dapat diukur dengan menggunakan tingkat perubahan kurs tengah Rupiah terhadap dollar AS.

Menghitung kurs tengah :

$$
\text { Kurs Tengah }=\frac{\text { Kurs Beli }+ \text { Kurs Jual }}{2}
$$

Adapun rumus menghitung kurs tengah adalah sebagai berikut:

Sedang kan rumus menghitung tingkat perubahan kurs rupiah terhadap dollar AS adalah sebagai berikut:

Tingkat Perubahan Kurs $=\frac{\text { Kurs Tengah t-Kurs Tengah } \mathrm{t}-1}{\text { Kurs Tengah } \mathrm{t}-1}$

Keterangan :

Kurs Tengah $\mathrm{t}$ : Nilai kurs tengah pada periode $\mathrm{t}$

Kurs tengah t-1 : Nilai kurs tengah periode pada periode sebelumnya

\section{Profitabiltas (ROE)}

Menurut Savitri (2012) "Return on Equity ini sering disebut dengan rate of return on Net Worth yaitu kemampuan perusahaan dalam menghasilkan keuntungan dengan modal sendiri yang dimiliki, sehingga ROE ini ada yang menyebut sebagai rentabilitas modal sendiri”. Return on equity atau rentabilitas modal sendiri merupakan rasio untuk mengukur laba bersih sesudah pajak dengan 


\title{
Vol 10 Nomor 2 (2020)
}

modal sendiri. Menurut Juwita (2013) "return on equity adalah rasio yang menunjukan perbandingan antara laba (setelah pajak) dengan modal (modal inti) bank, rasio ini menunjukan tingkat presentase yang dapat dihasilkan. Untuk menghitung rasio ROE menggunakan rumus, sebagai berikut:

$$
\text { Return On Equity (ROE): } \frac{\text { Laba Bersih }}{\text { Ekuitas }}
$$

\begin{abstract}
Aktivitas (TATO)
Pengertian total asset turnover menurut Kasmir (2009) "Total asset turnover merupakan rasio yang digunakan untuk mengukur perputaran semua aktiva yang dimiliki perusahaan dan mengukur berapa jumlah penjualan yang diperoleh dari setiap rupiah yang dihasilkan". Dapat disimpulkan bahwa Total asset turnover adalah rasio yang digunakan untuk mengukur efisiensi penggunaan seluruh aktiva untuk meningkatkan volume penjualan dengan cara membagi penjualan dengan total aktiva.
\end{abstract}

$$
\text { Total assets turn over }=\frac{\text { Penjualan }}{\text { Total Aktiva }}
$$

\section{Good Corporate Governance (Komisaris Independen)}

Good Corporate Governance merupakan konsep yang didasarkan pada teori keagenan (agency theory), yang diharapkan bisa berfungsi sebagai alat untuk memberikan keyakinan kepada para investor bahwa mereka akan menerima return atas dana yang telah mereka investasikan. Corporate Governance berkaitan dengan keyakinan para investor bahwa agent (manajer) akan memberikan keuntungan bagi mereka, keyakinan bahwa agent (manajer) tidak akan mencuri, menggelapkan bahkan menginvestasikan ke dalam proyek-proyek yang tidak menguntungkan berkaitan dengan dana yang telah ditanamkan oleh investor, dan berkaitan dengan bagaimana para investor mengontrol para agent (manajer). Dengan kata lain, corporate governance diharapkan dapat berfungsi untuk menekan atau menurunkan biaya keagenan (agency cost) Al-Haddad et al (2012).

Selain memiliki kinerja keuangan yang baik, perusahaan diharapkan juga memiliki tata kelola yang baik. Pengelolaan perusahaan yang baik akan mempengaruhi stakeholders untuk mau berinvestasi pada perusahaan tersebut. Mekanisme GCG yang digunakan dalam penelitian ini mengacu kepada mekanisme internal yaitu pengendalian yang dilakukan oleh dewan komisaris yaitu komisaris independen.

Board of Commisioner (Dewan Komisaris) bertugas dan bertanggungjawab secara kolektif untuk melakukan pengawasan dan memberikan nasihat kepada direksi serta memastikan bahwa perusahaan melaksanakan GCG. Selain itu Komite Nasional Kebijakan Governance menyatakan bahwa dewan komisaris terdiri dari komisaris yang tidak berasal dari pihak terafiliasi atau dikenal sebagai komisaris independen dan komisaris yang terafiliasi. Dewan komisaris yang berasal dari luar perusahaan akan meningkatkan efektivitas dalam mengawasi manajemen untuk mencegah terjadinya kecurangan dalam pembuatan laporan keuangan (Komite Nasional Kebijakan Governance, 2006).

$$
\text { Komisaris Independen }=\frac{\text { Jumlah Komisaris Independen }}{\text { Jumlah total komisaris yang ada dalam susunan dewan komisaris }}
$$

\section{Pengembangan Hipotesis}

Inflasi merupakan kecenderungan kenaikan harga barang-barang secara umum yang terjadi terus menerus akibat kebutuhan masyarakat yang meningkat. Hal ini tentu saja akan mempengaruhi kenaikan biaya produksi pada suatu perusahaan. Kenaikan harga barang produksi 


\section{Vol 10 Nomor 2 (2020)}

menjadi masalah tersendiri bagi perusahaan. Jika harga barang produksi naik, maka biaya operasional juga ikut naik, sehingga akan menurunkan tingkat laba perusahaan. Menurunnya tingkat laba tersebut akan mempengaruhi tingkat dividen yang akan dibagikan kepada pemegang saham. Jika dividen yang dibagikan mengalami penurunan, maka harga saham juga akan cenderung menurun sehingga berdampak pada menurunnya return saham yang akan diterima oleh investor.

Selain itu, inflasi juga menyebabkan turunnya daya beli uang. Jika daya beli uang menurun, maka pendapatan riil masyarakat termasuk investor, akan menjadi berkurang, sehingga keinginan investor untuk berinvestasi juga berkurang. Hal tersebut dapat menyebabkan harga saham mengalami penurunan. Jika harga saham menurun, maka return saham yang akan diterima investor akan berkurang. Berdasarkan penjelasan ini dapat disimpulkan bahwa terdapat pengaruh negatif dari perubahan tingkat inflasi terhadap return saham.

Hasil penelitian yang memperkuat teori di atas adalah penelitian yang dilakukan oleh Supriyanti dan Neni (2009) yang menunjukkan hasil bahwa inflasi berpengaruh negatif signifikan terhadap return saham. Selain itu, penelitian yang dilakukan oleh Suryanto (2007) juga menunjukkan hal sama, yaitu inflasi berpengaruh negatif signifikan terhadap return saham. Penelitian yang dilakukan oleh Utami dan Rahayu (2003) juga ikut memperkuat teori di atas, di dalam penelitiannya juga memberikan hasil bahwa inflasi berpengaruh negatif dan signifikan terhadap return saham. Penelitian yang dilakukan Ramadhan (2009) hasil penelitian bahwa Inflasi mempunyai pengaruh signifikan terhadap return saham. Berdasarkan penelitian Solikha (2014) bahwa hasil penelitian Tingkat inflasi berpengaruh negatif dan tidak signifikan terhadap return saham perbankan.

\section{H1: Inflasi Berpengaruh negatif terhadap Return saham}

Tingkat suku bunga BI merupakan suku bunga kebijakan yang mencerminkan sikap atau kebijakan yang ditetapkan oleh Bank Indonesia dan dipublikasikan kepada publik. Penetapan tingkat suku bunga oleh Bank Indonesia bertujuan untuk memberi rangsangan pada perbankan agar mengikuti skenario moneter. Harapannya, pergerakan tingkat suku bunga BI akan diikuti oleh pergerakan suku bunga kredit dan deposito.

Perubahan tingkat suku bunga BI akan memberikan pengaruh bagi pasar keuangan maupun pasar modal. Apabila tingkat suku bunga BI mengalami kenaikan, maka beban bunga yang harus ditanggung oleh perusahaan juga tinggi. Perusahaan yang memiliki leverage tinggi akan terkena dampak yang berat terhadap tingginya kenaikan tingkat suku bunga. Kenaikan tingkat suku bunga BI tersebut dapat mengurangi profitabilitas perusahaan, sehingga berpengaruh terhadap Return saham perusahaan yang bersangkutan dan berimbas pada return saham yang akan diterima investor. Berdasarkan Penelitian Ramadhan (2009) bahwa Suku bunga SBI tidak berpengaruh signifikan terhadap return saham. Berdasarkan hasil penelitian Meyfi dan Rudiyanto (2014) Suku Bunga BI Rate tidak akan memberikan pengaruh terhadap kontribusi dan signifikan terhadap perubahan return saham.

\section{H2: Suku Bunga berpengaruh negatif terhadap Return saham}

Kurs merupakan nilai tukar mata uang suatu negara terhadap mata uang negara lain. Informasi pasar mengenai melemahnya nilai tukar Rupiah membawa pengaruh negatif pada pasar ekuitas karena pasar ini menjadi kurang menarik bagi investor. Pialang saham, investor dan pelaku pasar modal biasanya sangat berhati-hati dalam menentukan posisi beli atau posisi jual jika nilai tukar mata uang tidak stabil. Oleh karena itu, dapat disimpulkan bahwa tingkat perubahan (melemah atau menguatnya) nilai tukar Rupiah terhadap dollar AS berpengaruh terhadap return saham. Berdasarkan penelitian Meyfi dan Rudianto (2014) bahwa hasil penelitian Kurs akan memberikan kontribusi positif yang signifikan terhadap perubahan return saham. Berdasarkan hasil penelitian Utami, M. dan Rahayu, Mudjilah, (2003) Bahwa pada perubahan tukar kurs yang mempengaruhi secara negatif terhadap return saham.

H3: Tingkat perubahan kurs berpengaruh terhadap Return saham 


\section{Vol 10 Nomor 2 (2020)}

Profitabilitas adalah hasil akhir dari sejumlah kebijakan dan keputusan manajemen perusahaan. Perusahaan yang memiliki tingkat profitabilitas yang tinggi akan diminati sahamnya oleh investor, sehingga profitabilitas dapat mempengaruhi return saham (Sari dkk, 2020). Returtn on Equity merupakan ukuran kemampuan perusahaan dalam menghasilkan keuntungan dengan menggunakan modal sendiri, sehingga ROE sering disebut sebagai rentabilitas modal sendiri.Tingkat ROE yang tinggi menunjukkan kemampuan perusahaan dalam menghasilkan laba bagi pemegang saham. Jika perusahaan dapat menghasilkan laba yang tinggi, maka permintaan akan saham akan meningkat dan selanjutnya akan berdampak pada meningkatnya harga saham perusahaan. Ketika harga saham semakin meningkat maka return saham juga akan meningkat. Wati d.k.k (2019) menunjukkan bahwa profitabilitas perusahaan berpengaruh positif terhadap nilai perusahaan. Widodo (2007), Jauhari dan Wibowo (2012) menunjukkan bahwa profitabilitas mempunyai pengaruh positif terhadap return saham. Penelitian yang dilakukan Inasari (2014-2016) berdasarkan analisis bahwa Roe tidak memiliki pengaruh tersignifikan terhadap return saham.

\section{H4: ROE berpengaruh positif terhadap Return saham}

Total Assets Turn Over digunakan untuk mengukur perputaran semua aktiva yang digunakan untuk mengukur berapa jumlah penjualan yang diperoleh dari tiap Rupiah aktiva Kasmir (2009). Semakin cepat tingkat perputaran aktivanya maka laba bersih yang dihasilkan akan semakin meningkat karena perusahaan sudah dapat memanfaatkan aktiva untuk meningkatkan penjualan yang berpengaruh terhadap pendapatan. Total Asset Turnover (TATO) pada return saham. Jika penjualan lebih besar dari total aktiva maka tingkat pengembalian keuntungan atau return yang didapat perusahaanakan tinggi, karena penjualan yang besar mencerminkan keuntungan yang besar bagi perusahaan. Sebaliknya, jika total aktiva yang tinggi dari pada penjualannya maka return atau tingkat pengembalian keuntungan akan rendah. Dari argumentasi diatas disimpulkan bahwa TATO berpengaruh positif pada return saham. Hal ini dikuatkan dengan bukti yang empiris yang dilakukan oleh Sari dan Venusita (2018) Widodo (2007) dan saniman (2006) yang menunjukkan hasil TATO berpengaruh positif terhadap return saham.

\section{H5: Total Asset Turnover (TATO) berpengaruh positif terhadap return saham.}

Adanya pemisahan antara kepemilikan dan pengendalian in juga menimbulkan permasalahan yang dikenal sebagai agency problem (konflik keagenan), yaitu adanya perbedaan kepentingan antara pemilik dan manajemen. Konflik keagenan ini muncul pada perusahaan publik dengan konsep struktur kepemilikan yang lama, dimana pemiliki (berdasarkan kepemilikan saham) mengharapkan perusahaannya bisa tumbuh dalam jangka panjang, sedangkan manajemen dalam menjalankan tugasnya lebih berorientasi kepada jangka pendek sesuai dengan kontrak masa kerjanya, dan dapat menyalahgunakan wewenang untuk kepentingan pribadi yang dibebankan kepada perusahaan (Retno, 2017). Corporate Governance merupakan konsep yang didasarkan pada teori keagenan (agency theory), yang diharapkan bisa berfungsi sebagai alat untuk memberikan keyakinan kepada para investor bahwa mereka akan menerima return atas dana yang telah mereka investasikan. Corporate Governance berkaitan dengan keyakinan para investor bahwa agent (manajer) akan memberikan keuntungan bagi mereka, keyakinan bahwa agent (manajer) tidak akan mencuri, menggelapkan bahkan menginvestasikan ke dalam proyek-proyek yang tidak menguntungkan berkaitan dengan dana yang telah ditanamkan oleh investor, dan berkaitan dengan bagaimana para investor mengontrol para agent (manajer). Dengan kata lain, corporate governance diharapkan dapat berfungsi untuk menekan atau menurunkan biaya keagenan (agency cost) Putri dan Ulupui (2017).

\section{H6: Good corporate governance berpengaruh positif terhadap return saham}

Profitabillitas menjadi cerminan dari perusahaan dalam mengukur kemampuan keuangan dari perusahaan tersebut terlebih Profitabilitas mengukur kemampuan perusahaan dalam memenuhi kewajiban dalam jangka pendek yang sudah jatuh tempo. Semakin besar kewajiban jangka pendek perusahaan dapat menunjukan semakin terpenuhinya kebutuhan operasional perusahaan untuk menjaga kelangsungan perusahaan itu sendiri Al-Haddad,dkk (2012). Hal itu dapat menjadi faktor 
untuk menaikan kepercayaan kepada para pemegang saham perusahaan tersebut, dan nantinya akan berdampak pada stabilnya return saham yang diterima perusahaan. Dengan diterapakannya praktek Good Corporate Governance pada perusahaan tersebut dapat memberikan dampak yang lebih baik lagi bagi perusahaan profitabitas terhadap return saham tersebut. Penelitian ini menambahkan faktor lain yang dimungkinkan turut mempengaruhi hubungan ROE dengan return saham yaitu pengungkapan good corporate governance (GCG) sebagai variabel moderasi yang diduga ikut memperkuat pengaruh tersebut.

\section{H7: Good corporate governance memperkuat pengaruh Profitabilitas terhadap Return saham}

Penelitian sebelumnya dilakukan oleh Heder (2017) menyatakan bahwa diterapkannya GCG maka manajemen perusahaan akan tertata dengan baik sehingga dapat meningkatkan rasio aktivitas (TATO) perusahaan itu sendiri dan meningkatnya kinerja keuangan yang ditunjang dari rasio aktivitas (TATO) perusahaan maka akan menjadi daya tarik bagi investor sehingga akan meningkatkan return saham. Hasil penelitian tersebut sejalan dengan penelitian yang dilakukan oleh Asji (2010), dan Imron dkk (2014) Bahwa GCG memperkuat pengaruh rasio aktivitas (TATO) pada return saham. Namun, Wati dkk (2019), menunjukkan hasil yang berbeda, dimana GCG tidak mampu meperkuat pengaruh profitabilitas terhadap nilai perusahaan. Berdasarkan teori dan hasil penelitian tersebut good corporate governance memperkuat pengaruh aktivitas pada return saham.

H8: Good corporate governance memperkuat pengaruh Aktivitas terhadap Return saham

\section{KERANGKA PIKIR}

Berdasarkan uraian di atas, dapat dibuat suatu kerangka pemikiran teoritis yang menggambarkan variabel-variabel yang mempengaruhi return saham yaitu:

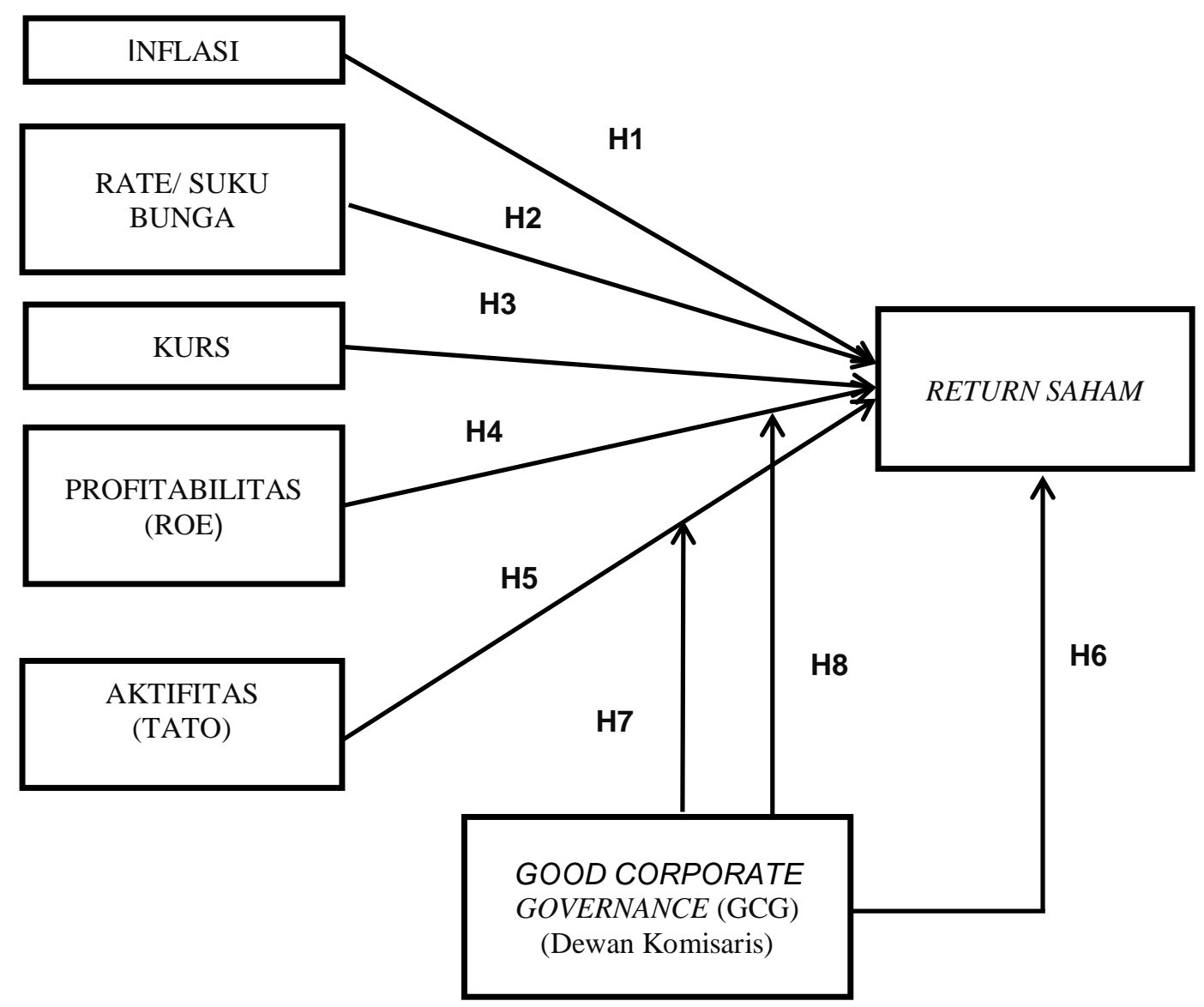

Gambar 1. Kerangka Pemikiran Penelitian 


\section{JURNAL EKOBIS: EKONOMI, BISNIS \& MANAJEMEN \\ Vol 10 Nomor 2 (2020)}

\section{METODE PENELITIAN}

Variabel dependen yang digunakan adalah return saham, variable independent menggunakan inflasi, suku bunga, kurs dan dewan komisaris independent sebagai proksi dari mekanisme internal GCG, komisaris independent juga merupakan variable moderasi. Unit analisis dalam penelitian ini adalah perusahaan perbankan yang terdatar di Bursak Efek Indonesia tahun 2014-2018, populasi dalam peneitian ini sejumlah 42 bank, namun setelah melewati teknik purposive sampling yang terpilih sebagai penelitian sejumlah 20 atau 100 sampel observasi.

Model persamaan regresi data panel dalam penelitian ini adalah sebagai berikut:

\section{Keterangan :}

$$
Y=\alpha+\beta_{1} x_{1}+\beta_{2} x_{2}+\beta_{3} x_{3}+\beta_{4} x_{4}+\beta_{5} x_{5}+\beta_{6} x_{6}+\beta_{7} x_{7}+\beta_{8} x_{8}+\varepsilon
$$

$$
\begin{array}{ll}
\mathbf{Y} & =\text { Return Saham } \\
\boldsymbol{a} & =\text { Konstanta } \\
\boldsymbol{x}_{1} & =\text { Inflasi } \\
\boldsymbol{x}_{2} & =\text { Suku Bunga/Rate } \\
\boldsymbol{x}_{3} & =\text { Kurs } \\
\boldsymbol{x}_{4} & =\text { Roe } \\
\boldsymbol{x}_{5} & =\text { Aktivitas (Tato) } \\
\boldsymbol{x}_{6} & =\text { GCG (good corporate governance) } \\
\boldsymbol{x}_{7} & =\text { GCG moderasi Roe } \\
\boldsymbol{x}_{8} & =\text { GCG moderasi Tato } \\
\boldsymbol{\varepsilon} & =\text { Erorr }
\end{array}
$$

Pengujian hipotesis dilakukan dengan membandingkan t-statistik dengan t-tabel atau dengan membandingkan tingkat signifikansi atau p-value (Wati, 2018).

\section{ANALISIS DATA DAN PEMBAHASAN}

Tabel 3. Deskriptif Variabel Penelitian

\begin{tabular}{|c|c|c|c|c|c|c|c|c|}
\hline VARIABEL & RETURN & INFLASI & RATE & KURS & ROE & TATO & BOARD & SIZE \\
\hline Mean & 0.156010 & 0.043080 & 0.060500 & 0.000847 & 9.411500 & 0.081111 & 4.850000 & 7.879700 \\
\hline Median & 0.047129 & 0.033500 & 0.060000 & -0.002486 & 8.545000 & 0.084899 & 4.500000 & 8.010000 \\
\hline Maximum & 3.490066 & 0.083600 & 0.077500 & 0.108923 & 24.82000 & 0.163877 & 8.000000 & 9.080000 \\
\hline Minimum & -0.725526 & 0.030200 & 0.042500 & -0.002503 & 0.680000 & 0.007360 & 3.000000 & 6.680000 \\
\hline Std. Dev. & 0.504325 & 0.020455 & 0.014160 & 0.011383 & 5.239739 & 0.034478 & 1.597820 & 0.703664 \\
\hline Observations & 100 & 100 & 100 & 100 & 100 & 100 & 100 & 100 \\
\hline
\end{tabular}

Sumber: Data diolah, 2019

Berdasarkan tabel 3 dapat dilihat nilai terendah (minimum) return saham sebesar -0.725526 dicapai oleh bank Rakyat Indonesia Tbk (BBRI) pada annual report tahun 2015. Nilai tertinggi (maximum) sebesar 3.490066 dicapai oleh bank Jabar Banten (BJBR) pada tahun 2016. Rata-rata (mean) sebesar 0.156010 dan standar deviasi sebesar 0.504325. Nilai teredah (minimum) Inflasi sebesar 0.030200 dicapai oleh semua perbankan dalam penelitian annual report pada tahun 2016 . Nilai tertinggi (maximum) sebesar 0.0863600 dicapai oleh semua perbankan dalam penelitian annual 
report pada tahun 2014. Rata-rata (mean) 0.043080 dan standar devisiasi sebesar 0.020455. Nilai terendah (minimum) tingkat suku bunga sebesar 0.042500 dicapai oleh semua perbankan dalam penelitian pada tahun 2017. Nilai tertinggi (maximum) sebesar 0.077500 dicapai oleh semua perbankan dalam penelitian pada tahun 2014. Rata-rata (mean) 0.060500 dan standar devisiasi sebesar 0.014160. Nilai terendah (minimum) Tingkat perubahan kurs rupiah terhadap dollar AS sebesar 0.002503 dicapai oleh semua perbankan pada tahun 2015. Nilai tertinggi (maximum) sebesar 0.108923 dicapai oleh semua perbankan pada tahun 2017. Rata-rata (mean) sebesar 0.000847 dan standar deviasi sebesar .011383. Nilai terendah (minimum) return saham sebesar 0.680000 dicapai oleh bank Nusantara Parahyangan Tbk pada annual report tahun 2016. Nilai tertinggi (maximum) 24.82000 dicapai oleh bank Rakyat Indonesia (BBRI) pada tahun 2014. Rata-rata (mean) sebesar 9.411500 dan standar deviasi sebesar 5.239739. Nilai terendah (minimum) Dewan Komisaris sebesar 3.000000 dicapai 5 perbankan yaitu Bank Bukopin Tbk, Bank Jabar Banten Tbk, Bank Sinarmas Tbk, Bank Bumi Arta Tbk, Dan Bank Capital Tbk pada tahun 2014-2018. Nilai tertinggi (maximum) 8.000000 Dicapai 2 perbankan yaitu Bank Cimb Niaga Tbk, dan Bank OCBC Nisp Tbk pada tahun 2014-2018. Rata-rata (mean) sebesar 4.8500000 dan standar deviasi sebesar 1.597820 .

Tabel 4. Hasil Pengujian Model Penelitian

\begin{tabular}{|c|c|c|c|c|c|}
\hline Variabel & Prediksi & Main Model & Hipotesis & Robust & Hipootesis \\
\hline $\mathrm{c}$ & & -0.9517 & & -0.5025 & \\
\hline Inflasi & $\beta-$ & $\begin{array}{l}1.8815 \\
(1.0393)\end{array}$ & $\begin{array}{l}\text { Tidak } \\
\text { Didukung }\end{array}$ & $\begin{array}{l}1.8099 \\
(1.0009)\end{array}$ & $\begin{array}{l}\text { Tidak } \\
\text { Didukung }\end{array}$ \\
\hline Rate & $\beta-$ & $\begin{array}{l}-7.8237 * * * \\
(-3.0348)\end{array}$ & Didukung & $\begin{array}{l}-8.1811 * * * \\
(3.1505)\end{array}$ & Didukung \\
\hline Kurs & $\beta-$ & $\begin{array}{l}-7.0278 * * * \\
(-3.4284)\end{array}$ & Didukung & $\begin{array}{l}-7.2635 * * * \\
(-3.5826)\end{array}$ & Didukung \\
\hline ROE & $\beta+$ & $\begin{array}{l}0.0437 \\
(1.4270)\end{array}$ & $\begin{array}{l}\text { Tidak } \\
\text { Didukung }\end{array}$ & $\begin{array}{l}0.0526 \\
(1.7759)\end{array}$ & $\begin{array}{l}\text { Tidak } \\
\text { Didukung }\end{array}$ \\
\hline TATO & $\beta+$ & $\begin{array}{l}10.2931 \text { *** } \\
(2.8014)\end{array}$ & didukung & $\begin{array}{l}9.5712 * * * \\
(2.6275)\end{array}$ & Didukung \\
\hline BOARD (GCG) & $\beta+$ & $\begin{array}{l}0.17821 * * \\
(2.0350)\end{array}$ & Didukung & $\begin{array}{l}0.1963 * * \\
(2.2665)\end{array}$ & Didukung \\
\hline BOARD*ROE & $\beta+$ & $\begin{array}{l}-0.0086 \\
(-1.4321)\end{array}$ & $\begin{array}{l}\text { Tidak } \\
\text { Didukung }\end{array}$ & $\begin{array}{l}-0.0096 \\
(-1.6107)\end{array}$ & $\begin{array}{l}\text { Tidak } \\
\text { Didukung }\end{array}$ \\
\hline BOARD*TATO & $\beta+$ & $\begin{array}{l}-1.8989 * * * * \\
(-2.6931)\end{array}$ & $\begin{array}{l}\text { Tidak } \\
\text { Didukung }\end{array}$ & $\begin{array}{l}-1.8140 * * * \\
(-2.5636)\end{array}$ & $\begin{array}{l}\text { Tidak } \\
\text { Didukung }\end{array}$ \\
\hline Size & $\beta+$ & $\begin{array}{l}0.0670 \\
(1.0910)\end{array}$ & - & $\begin{array}{l}- \\
-\end{array}$ & $\begin{array}{l}- \\
-\end{array}$ \\
\hline$R^{2}$ & & $31.41 \%$ & & $30.95 \%$ & \\
\hline $\operatorname{Adj} R^{2}$ & & $24.55 \%$ & & $24.88 \%$ & \\
\hline F-Statistik & & $4.581 * * *$ & & $5.098 * * *$ & \\
\hline
\end{tabular}

Keterangan: ***Signifikan 1\%,**Signifikan 5\%, *Signifikan 10\%

Sumber: Data diolah, 2019 


\section{Vol 10 Nomor 2 (2020)}

Pengujian hipotesis secara parsial dilakukan dengan membandingkan $t_{\text {statistik }}$ dengan $t_{\text {tabel }}$ ataupun dengan melihat nilai signifikan. Koefisien regresi yang diperoleh dari pengaruh variabel inflasi terhadap return saham adalah sebesar 1.8815 dengan nilai $t_{\text {statistik }} 1.0393<1.96$, pada taraf signifikansi $\alpha=0.05(5 \%)$ dengan nilai signifikansi $0.3014>0.05$ yang menyatakan bahwa inflasi tidak berpengaruh terhadap return saham. Hasil penelitian ini tidak mendukung hipotesis pertama dimana inflasi tidak berpengaruh signifikan terhadap return saham. Bukti empiris ini tidak mendukung teori dan peneliti sebelumnya (Neni, 2009; Ramadhan, 2009) yang menunjukkan bahwa kenaikan inflasi mampu menurunkan return saham perusahaan, namun mendukung peneliti sebelumnya yitu penelitian Solikha (2014) yang menunjukkan bahwa tingkat inflasi tidak berpengaruh signifikan terhadap return saham perbankan, artinya tingkat inflasi bukan faktor penentu dari return perusahaan perbankan.

Koefisien regresi yang diperoleh dari pengaruh variabel suku bunga (rate) terhadap return saham adalah sebesar -7.8237 dengan nilai $t_{\text {statistik }} 3.0348>1.96$, pada taraf signifikansi $\alpha=0.05(5 \%)$ dengan nilai signifikansi $0.0031<0.05$ yang menyatakan bahwa bunga (rate) berpengaruh negative siginifikan terhadap return saham. Hasil penelitian ini mendukung hipotesis kedua dimana suku bunga (rate) berpengaruh negatif signifikan terhadap return saham. Hasil penelitian ini sesuai dengan peneliti sebelumnya yaitu Meyfi dan Rudiyanto (2014) yang menunjukkan bahwa tingkat sukubunga (rate) berpengaruh negative siginifikan terhadap return saham. Perubahan tingkat suku bunga BI akan memberikan pengaruh bagi pasar keuangan maupun pasar modal. Apabila tingkat suku bunga BI mengalami kenaikan, maka beban bunga yang harus ditanggung oleh perusahaan juga tinggi. Perusahaan yang memiliki leverage tinggi akan terkena dampak yang berat terhadap tingginya kenaikan tingkat suku bunga. Kenaikan tingkat suku bunga BI tersebut dapat mengurangi profitabilitas perusahaan, sehingga berpengaruh terhadap Return saham perusahaan yang bersangkutan dan berimbas pada return saham yang akan diterima investor.

Koefisien regresi yang diperoleh dari pengaruh variabel kurs terhadap return saham adalah sebesar -7.0278 dengan nilai $\mathrm{t}_{\text {statistik }} 3.0348>1.96$, pada taraf signifikansi $\alpha=0.05(5 \%)$ dengan nilai signifikansi $0.0009<0.05$ yang menyatakan bahwa kurs berpengaruh negative signifikan terhadap return saham. Hasil penelitian ini mendukung hipotesis ketiga dimana rate berpengaruh signifikan terhadap return saham. Bukti empiris ini sependapat dengan peneliti sebelumnya yaitu Utami dan Rahayu, Mudjilah, (2003), yang menyatakan bahwa perubahan kurs berpengaruh negative terhadap return saham perbankan.

Koefisien regresi yang diperoleh dari pengaruh variabel ROE terhadap return saham adalah sebesar 0.0437 dengan nilai $\mathrm{t}_{\text {statistik }} 1.4270<1.96$, pada taraf signifikansi $\alpha=0.05(5 \%)$ dengan nilai signifikansi $0.1570>0.05$ yang menyatakan bahwa ROE tidak berpengaruh terhadap return saham. Hasil penelitian ini tidak mendukung hipotesis keempat dimana ROE tidak berpengaruh signifikan terhadap return saham. Hasil penelitian ini mendukung penelitian Inasari (2016), namun bertentangan dengan Widodo (2007), Jauhari dan Wibowo (2012). Artinya, profitabilitas perbankan bukan factor penentu dari return saham perusahaan.

Koefisien regresi yang diperoleh dari pengaruh variabel TATO terhadap return saham adalah sebesar 10.2931 dengan nilai $t_{\text {statistik }} 2.8014>1.96$, pada taraf signifikansi $\alpha=0.05(5 \%)$ dengan nilai signifikansi $0.0062<0.05$ yang menyatakan bahwa TATO berpengaruh terhadap return saham. Hasil penelitian ini mendukung hipotesis kelima dimana TATO berpengaruh positif dan signifikan terhadap return saham. Hasil penelitian ini mendukung Widodo (2007) dan saniman (2006) yang menunjukkan hasil TATO berpengaruh positif terhadap return saham. Semakin cepat tingkat perputaran aktivanya maka laba bersih yang dihasilkan akan semakin meningkat karena perusahaan sudah dapat memanfaatkan aktiva untuk meningkatkan penjualan yang berpengaruh terhadap pendapatan. Aktivitas yang tinggi ini dapat menarik minat investor untuk investasi di perusahaan tersebut, sehingga return saham perusahaan perbankan dapat meningkat. 


\section{Vol 10 Nomor 2 (2020)}

Koefisien regresi yang diperoleh dari pengaruh variabel Good corporate governance (GCG) terhadap return saham adalah sebesar 0.1782 dengan nilai $t_{\text {statistik }} 2.0350>1.96$, pada taraf signifikansi $\alpha=0.05(5 \%)$ dengan nilai signifikansi $0.0448<0.05$ yang menyatakan bahwa GCG berpengaruh positif signifikan terhadap return saham. Hasil penelitian ini mendukung penelitian Putri dan Ulupui (2017), dimana mekanisme GCG berpengaruh positif signifikan terhadap return saham. Adanya dewan komisaris di perbankan dapat meningkatkan control dan monitoring perbankan dengan baik sehingga memberikan keyakinan kepada investor bahwa agent (manajer) akan memberikan keuntungan bagi mereka, keyakinan bahwa agent (manajer) tidak akan mencuri, menggelapkan bahkan menginvestasikan ke dalam proyek-proyek yang tidak menguntungkan berkaitan dengan dana yang telah ditanamkan oleh investor, dan berkaitan dengan bagaimana para investor mengontrol para agent (manajer).

Koefisien regresi yang diperoleh dari pengaruh variabel ROE diukur dengan GCG terhadap return saham adalah sebesar -0.0086 dengan nilai tstatistik $1.4321<1.96$, pada taraf signifikansi $\alpha=$ $0.05(5 \%)$ dengan nilai signifikansi $0.1556>0.05$ yang menyatakan bahwa GCG tidak mampu memperkuat pengaruh profitabilitas terhadap return saham. Hasil penelitian ini tidak mendukung hipotesis dimana peran dewan komisaris dalam menekan manajemen untuk menghasilkan profit tidak berdampak terhadap return saham. Hasil ini sependapat dengan penelitian Wati dkk (2019). Perbedaan kepentingan antara menajer sebagai agent dengan pemegang saham sebagai principal akan menimbulkan agency conflict, kondisi ini terjadi karena agen lebih mengutamakan kepentingan pribadinya dibandingkan kepentingan pemegang saham. Perbedaan kepentingan ini akan menyebabkan agency cost yang besar yang dapat berpengaruh terhdap keuntungan perusahaan sehingga berdampak terhadap turunnya harga saham dan return saham. Adanya dewan komisaris di perusahaan tidak mampu memperkuat pengaruh profitabilitas perbankan terhadap harga saham perusahaan (Wati dkk, 2019).

Koefisien regresi yang diperoleh dari pengaruh variabel TATO diukur dengan GCG terhadap return saham adalah sebesar -1.8989 dengan nilai $\mathrm{t}_{\text {statistik }} 2.6931>1.96$, pada taraf signifikansi $\alpha=$ $0.05(5 \%)$ dengan nilai signifikansi $0.0084<0.05$ yang menyatakan bahwa GCG tidak mampu memperkuat pengaruh aktivitas terhadap return saham. Hasil penelitian ini mendukung hipotesis ke delapan dimana TATO diukur dengan GCG terhadap return saham berpengaruh signifikan terhadap return saham. Hasil penelitian ini tidak mendukung hipotesis dimana peran dewan komisaris dalam menekan manajemen untuk menghasilkan aktivitas yang tinggi tidak berdampak terhadap return saham.

Dari hasil tabel diatas terdapat kontrol variabel yaitu size yang berpengaruh positif tidak signifikan terhadap return saham. Hasil ini menunjukkan bahwa semakin besar perusahaan maka return saham juga akan meningkat, namun hasilnya tidak signifikan. Dilihat dari robust tes model, dimana variabel kontrol yaitu size yang dihilangkan, menunjukkan hasil pengujian yang konsisten dengan model penelitian utama.

Model penelitian dari tabel 4 diatas, dapat dijelaskan sebagai berikut:

$$
\begin{aligned}
\text { Return }= & -0.9517+1.8815 \text { inflasi }+-7.8237 \text { Rate }+-7.0278 \text { Kurs } \\
& +0.0437 \text { profitabilitas }+10.2931 \text { activitas }+0.1782 G C G+\text { GCG } \\
& +-0.0086 \text { profitabilitas }+ \text { GCG }+-1.8989 \text { Actifitas }++\varepsilon
\end{aligned}
$$

Dari persamaan regresi tersebut dapat disimpulkan bahwa nilai koefisien konstanta sebesar 0.9517 artinya jika variabel X1 (inflasi), X2( Rate), X3(kurs), X4(Profitabilitas), X5(Activitas) adalah nol, maka besarnya return saham sebesar -.09517. 


\section{Vol 10 Nomor 2 (2020)}

Nilai R-square (determinasi) sebesar 0.3141, artinya return saham dipengaruhi oleh inflasi, rate, kurs, profibilitas, activitas dan GCG sebesar $31.41 \%$ dan sisanya sebesar $68.591 \%$ dipengaruhi oleh faktor lain diluar penelitian.

\section{PENUTUP}

\section{Simpulan}

Berdasarkan hasil analisis dan pembahasan yang telah dilakukan, maka dapat diberikan kesimpulan bahwa hasil penelitian menunjukkan bahwa tingkat suku bunga dan kurs (faktor eksternal), profitabilitas, aktivitas, dan mekanisme GCG (faktor internal) berpengaruh signifikan terhadap retrun saham. Namun, GCG yang diproksi oleh dewan komisaris tidak mampu memperkuat pengaruh Profitabilitas dan Aktivitas terhadap return saham, begitu juga dengan inflasi tidak berpengaruh terhadap return saham. Besarnya jumlah dewan komisaris di perbankan tidak mampu memperkuat pengaruh kinerja keuangan perusahaan terhadap return saham.

\section{Saran}

Berdasarkan hasil penelitian, terdapat beberapa saran dan masukan yaitu untuk manajemen agar terus meningkatkan efektifitas dan efisiensi agar kinerja perbankan terus meningkat karena akan berdampak terhadap harga dan return saham. Bagi investor, agar memperhatikan rasio Total Asset Turn Over untuk menilai tingkat efektifitas dan efisiensi perbankan sebelum menginvestakikan dana di perusahaan juga melihat mekanisme Corporate Governance di perbankan. Pihak manajemen dan investor juga harus memperhatikan nilai kurs dan tingkat suku bunga karena berdampak terhadap return saham. Penelitian yang akan datang diharapkan dapat menggunakan rasio keuangan lainnya serta memperluas sampel penelitian dan mengelompokkan klasifikasi perbankan sesuai dengan kapitalisasinya (Buku 1-4).

\section{REFERENSI}

Al-Haddad, Waseem., Alzurqan, S T., dn AL-Sufy, F. J,. (2012). "Effect of corporate governance on the performance of jordanian industrial companies: an empirical study on the amman stock exchange".

Juwita, C. (2013). Pengaruh Variabel Roa, Roe, Der, Eps Dan Per Terhadap Return Saham Pada Perusahaan Non Bank Lq45 Yang Terdaftar Di Bursa Efek Indonesia (Doctoral dissertation, Universitas Brawijaya).

Darmawi, H. (2006). Pasar financial dan lembaga-lembaga finansial. Jakarta: Burni Aksara.

Fakhruddin dan Sopian Hadianto. ( 2001). Perangkat dan Model Analisis Investasi di Pasar Modal, Buku satu. Jakarta: Elex Media Komputindo.

Fathimah Mayfi dan Dudi Rudianto (2014),. Analisis pengaruh faktor internal dan eksternal perusahaan terhadap return saham.

Hadi, N.(2013). Pasar Modal. ( Edisi 1). Yogyakarta: Graha Ilmu.

Heder,(2017). Pengaruh kinerja keuangan terhadap nilai perusahaan dengan good coporate governance sebagai variabel pemoderasi. Jurnal ilmu dan riset akuntansi,6(7), 309-321.

Hakim, H., Wardini, A. K., \& Wati, L. N. (2020). Comparative Analysis Of Sharia And Non-Sharia Stock Portfolio Performance In 2012-2019. Journal of Information System, Applied, Management, Accounting and Research, 4(3), 67-79.

Hermawati, Angra, (2012). Pengaruh Kinerja Keuangan Terhadap Nilai Perusahaan Dengan Pengungkapan Corporate Social Responbility Dan Struktur Kepemilikan Sebagai Variabel Pemoderasi, Jakarta: Universitas Gunadarma.

Inasari, D. 2016. Pengaruh ROA, ROE, EPS dan DER terhadap return saham pada perusahaan indeks LQ45 yang terdaftar di bursa efek indonesia (BEI) PERIODE 2014-2016.

Imron,G.S., Hidayat, R., \& Alliyah, S.(2014). Pengaruh kinerja keuangan dan ukuran perusaan terhadap nilai perusahaan. Potensio,18(2),82-93. 


\section{Vol 10 Nomor 2 (2020)}

Kasmir, (2009). Analisis laporan keuangan, jakarta: PT. Raja Grafindo Persada.

Nurfinda, L., \& Venusita, L. (2018). Pengaruh kinerja keuangan terhadap return saham perusahaan property dan real estate. BISMA (Bisnis dan Manajemen), 6(2), 89-97.

Putri, I.G.M.A.D., \& Ulupui, I.G.K.A. (2017), pengantar corporate governance. Denpasar: cv.sastra utama.

Rachman, H.Y., Wati, L.N., Riadi, R. 2019. Analisis Perbandingan Kinerja Keuangan Bank Syariah dengan Bank Konvensional. Jurnal Akuntansi STIE Muhammadiyah Jakarta. Vol. 8 No. 2. Hal. 94-108.

Rahmad Ramadhan,. Pengaruh faktor-faktor internal dan eksternal perusahaan terhadap return saham pada perusahaan manufaktur sektor industri barang konsumsi yang terdapat di bursa efek indonesia periode 2009-2013.

Retno, D. (2017). Pengaruh csr dan enviromental performance terhadap nilai perusahaan dengan gcg variabel moderating. Jurnal ilmiah dan ilmu akuntansi, 6(11),1-24.

Sari, M.A., Wati, L.N., Rahardjo, B. 2020. Peran Profitabilitas dalam Memoderasi Pengaruh Struktur Modal dan Kebijakan Dividen terhadap Nilai Perusahaan. Jurnal Akuntansi STIE Muhammadiyah Jakarta. Vol. 9, No. 1. Hal. 1-13.

Sabat Nugroho Asji SE,(2010). Pengaruh moderasi pengungkapan corporate social responbility $(C S R)$ dan good corporate governance $(G C G)$ terhadap hubungan return on equity (ROE) pada Return Saham.

Savitri, (2012). Analisis pengaruh nilai tukar ung, suku bunga dan inflasi terhadap return saham sektor properti yang tercatat di bursa efek jakarta tahun 2001-2005. Tesis program studi manajemen program pasca sarjana universitas diponegoro, semarang.

Supriyanti, Neni. (2009). Analisis pengaruh inflasi dan suku bunga BI terhadap kinerja keuangan PT bank mandiri berdasarkan Rasio keuangan. Jakarta: Universitas Gunadarma.

Tandelilin, E. (2010). Portofolio dan Investasi: Teori dan aplikasi. Kanisius.

Utami, M, dan Rahayu,M, 2003, "analisis pengruh nilai tukar kurs, suku bunga,inflasi, dan pertumbuhan GDP terhadap pergerakan indeks return saham gabungan di bursa efek indonesia,"jurnal ekonomi manajemen, vol 5.no.2, jakarta.

Ulupui, I. G. K. A. (2014). Analisis Pengaruh Rasio Likuiditas, Leverage, Aktivitas, dan Profitabilitas Terhadap Return Saham. Universitas Udayana.

Wati, L. N., Rachmat Sudarsono, S. E., Si, M., \& Erie Febrian, S. E. (2016). Corporate Governance On Conglomerates Pollitically Connected. International Journal of Business, Economics and Law, 10(1), 23-31.

Wati, L. N. 2017. Board of commissioner's effectiveness on politically connected conglomerates:Evidence from Indonesia. Pertanika Journal Social Sciences \& Humanities, 25(S), pp. 255-270.

Wati, L.N. 2018. Metodologi Penelitian Terapan dengan Aplikasi SPSS, EVIEWS, SmartPLS, dan AMOS. Jakarta: Pustaka Amri.

Wati, L.N., Syahdam, G.R., Prambudi, B. (2019). Peran Pengungkapan CSR dan Mekanisme GCG Pada Kinerja Keuangan terhadap Nilai Perusahaan. Ecodemica. Vol. 3 No. 2. Pp. 98-110.

Wibowo,P.(2012). Pengaruh inventory turnover,return on asset, dan debt to equity ratio terhadap return saham pada perusahaan manufaktur yang terdaftar di bursa efek indonesia tahun 20082013. Skripsi. Universitas Negri yogyakarta.

Widodo, (2007). Analisis pengaruh rasio aktivitas, rasio profibilitas dan rasio pasar terhadap return saham syariah dalam kelompok jakarta islamic index(JII) tahun 2003-2005[on-line] available. 